\title{
Performance of broiler chicken fed multicarbohydrases supplemented low energy diet
}

\author{
Kumar Govil, Sunil Nayak, R. P. S. Baghel, A. K. Patil, C. D. Malapure and Dinesh Thakur \\ Department of Animal Nutrition, College of Veterinary Science and Animal Husbandry, Jabalpur - 482001 , \\ Madhya Pradesh, India. \\ Corresponding author: Sunil Nayak, e-mail: sunilnayak91@yahoo.com \\ Co-authors: KG: kumargovil100@rediffmail.com, RPSB: rameshbaghel@yahoo.co.in, AKP: ashokdrpatil@gmail.com, \\ CDM: cdmalapure@gmail.com, DT: dthakur023@gmail.com \\ Received: 03-03-2017, Accepted: 19-05-2017, Published online: 02-07-2017
}

doi: 10.14202/vetworld.2017.727-731 How to cite this article: Govil K, Nayak S, Baghel RPS, Patil AK, Malapure CD, Thakur D (2017) Performance of broiler chicken fed multicarbohydrases supplemented low energy diet, Veterinary World, 10(7): 727-731.

\begin{abstract}
Aim: Objective of this study was to investigate the effect of multicarbohydrases supplementation on performance of broilers fed low energy diet.

Materials and Methods: A total of 75 days old chicks were selected and randomly divided into three treatments groups $\left(\mathrm{T}_{1}, \mathrm{~T}_{2}\right.$, and $\mathrm{T}_{3}$ ); each group contained 25 chicks distributed in five replicates of five chicks each. $\mathrm{T}_{1}$ group (positive control) was offered control ration formulated as per Bureau of Indian Standards recommendations. In $\mathrm{T}_{2}$ group (negative control) ration, metabolizable energy (ME) was reduced by $100 \mathrm{kcal} / \mathrm{kg}$ diet. $\mathrm{T}_{3}$ group ration was same as that of $\mathrm{T}_{2}$ except that it was supplemented with multicarbohydrases (xylanase at $50 \mathrm{~g} / \mathrm{ton}+$ mannanase at $50 \mathrm{~g} /$ ton+amylase at $40 \mathrm{~g} /$ ton). Feed intake and body weight of all experimental birds were recorded weekly. Metabolic trial was conducted for 3 days at the end of experiment to know the retention of nutrients.
\end{abstract}

Results: Significant improvement $(\mathrm{p}<0.01)$ was observed in total weight gain, feed conversion efficiency, and performance index in broilers under supplementary group $T_{3}$ as compared to $T_{1}$ and $T_{2}$ groups. Retention of crude protein and ether extract was significantly increased $(\mathrm{p}<0.05)$ in $\mathrm{T}_{3}$ group supplemented with multicarbohydrases as compared to other groups. Retention of dry matter, crude fiber, and nitrogen-free extract was comparable in all the three groups. Significantly highest dressed weight, eviscerated weight, and drawn weight (\% of live body weight) were observed in multicarbohydrases supplemented $\mathrm{T}_{3}$ group, however it was comparable in $\mathrm{T}_{1}$ and $\mathrm{T}_{2}$ groups.

Conclusion: It was concluded that the supplementation of multicarbohydrases (xylanase at $50 \mathrm{~g} /$ ton + mannanase at $50 \mathrm{~g} /$ ton+amylase at $40 \mathrm{~g} / \mathrm{ton}$ ) in low energy diet improved overall performance of broilers.

Keywords: broiler, carcass traits, multicarbohydrases, performance.

\section{Introduction}

Corn is a highly digestible source of energy and it also provides various other nutrients including amino acids. It is main source of energy in poultry diets on a global scale including India and its inclusion rate in commercial diets can be up to $70 \%$. Corn and soybean meal are two major ingredients in commercial poultry diets in many parts of the world which contain lower concentration of antinutritive high molecular weight-soluble nonstarch polysaccharides (NSP) that can impede normal digestion and absorption processes of nutrients including carbohydrates and proteins in the digestive tract. A combination of undigested fat, protein, and starch contributes to energy loss and use of exogenous enzymes can be a good strategy to make this energy available to birds. About 400-450 kcal of

Copyright: Govil, et al. Open Access. This article is distributed under the terms of the Creative Commons Attribution 4.0 International License (http://creativecommons.org/licenses/by/4.0/), which permits unrestricted use, distribution, and reproduction in any medium, provided you give appropriate credit to the original author(s) and the source, provide a link to the Creative Commons license, and indicate if changes were made. The Creative Commons Public Domain Dedication waiver (http://creativecommons.org/ publicdomain/zero/1.0/) applies to the data made available in this article, unless otherwise stated. energy per $\mathrm{kg}$ of diet is not digested when birds are fed a typical corn-soya ration [1]. Nowadays, various exogenous enzymes are being used in poultry diets to improve feed utilization. The exogenous enzymes are used either to correct the lack of specific endogenous enzymes for digesting certain nutrients in various feedstuffs or to hydrolyze antinutritional factors in feed ingredients.

The use of exogenous feed enzymes in poultry diets is becoming popular to overcome the adverse effects of antinutritional factors and to improve digestion of dietary components and bird performance [2]. The NSP degrading enzyme products can enhance the access of endogenous enzymes to nutrients (e.g., starch granules) by releasing the nutrients from complex cell wall molecules [3]. Supplemental multicarbohydrases (amylase, xylanase, and mannase) increased the digestibility of nutrients in broiler chicken fed corn-based diets [4-6].

The existing knowledge on the role of exogenous enzyme in enhancing the feeding value of corn-soy diets in poultry is not only limited but also inconsistent. Keeping in view this brief background, this study was planned to investigate the effect of 
multicarbohydrases (exogenous enzyme) supplementation on performance of broilers fed low energy diet.

\section{Materials and Methods \\ Ethical approval}

The experimental design and plan of this study strictly followed the norms of the Institutional Animal Ethics Committee of Nanaji Deshmukh Veterinary Sciences University Jabalpur, Madhya Pradesh.

\section{Study area}

The proposed experiment was conducted in the Department of Animal Nutrition, College of Veterinary Science and Animal Husbandry, Jabalpur, Madhya Pradesh.

\section{Experimental design}

A total of 75 days old cobb 400 chicks were randomly divided into three treatments groups $\left(\mathrm{T}_{1}, \mathrm{~T}_{2}\right.$ and $\mathrm{T}_{3}$ ); each group contained 25 chicks distributed in five replicates of five chicks each. $T_{1}$ group (positive control) was offered control corn-soy based ration in mash form formulated as per Bureau of Indian Standards [7] recommendations. In $T_{2}$ group (negative control) ration, metabolizable energy (ME) was reduced by $100 \mathrm{kcal} / \mathrm{kg}$ diet. $\mathrm{T}_{3}$ group ration was same as that of $T_{2}$ except that it was supplemented with commercially available multicarbohydrases (xylanase at $50 \mathrm{~g} /$ ton + mannanase at $50 \mathrm{~g} /$ ton + amylase at $40 \mathrm{~g} /$ ton). All the three enzymes, i.e., xylanase $(1,200,000 \mathrm{IU} / \mathrm{g})$, mannase $(200,000 \mathrm{IU} / \mathrm{g})$, and amylase $(160,000 \mathrm{IU} / \mathrm{g})$ were purchased individually and incorporated in the feed. Enzymes were heat stable and able to with stand pelletization temperature up to $90^{\circ} \mathrm{C}$ for $90 \mathrm{~s}$. The doses of enzymes were decided on the basis of review of literature available.

Ingredients and nutrient composition of all the experimental diets for prestarter, starter and finisher phase are presented in Table-1. Total experimental period was of 6 weeks.

The experimental chicks were reared in the battery brooder house. The battery brooders were cleaned washed and fumigated using formaldehyde and potassium permanganate four days before start of the experiment. Artificial heat was provided to chicks during the early period of growth using electric bulbs. In addition, room heaters were also used to maintain the room temperature as the experiment was conducted in spring season. Mash feed was offered ad libitum to the broilers in feeders. Care was taken that feeders are full of feed at all time and constant watch was kept to avoid feed wastage. An ample supply of clean and fresh drinking water was made available to the birds all the time through simple water channel type waterer.

\section{Data recording}

All the experimental chicks were weighed at the beginning of the experiment and subsequently at weekly intervals to estimate total weight gain, average daily gain, and feed efficiency ratio (FER). Weekly feed consumption of broilers was recorded replicate wise on the basis of feed offered and left over at the end of that week. Performance index (PI) was calculated as per the formula given below proposed by Bird [8].

\section{$\mathrm{PI}=$ Body weight gain $(\mathrm{g}) \times \mathrm{FER}$}

The metabolic trial was conducted for 3 days at the end of experiment to know the retention of nutrients (dry matter [DM], crude protein [CP], ether extract $[\mathrm{EE}]$, crude fiber $[\mathrm{CF}]$, and nitrogen free extract [NFE]). To study the carcass traits (dressed weight, eviscerated weight, and drawn weight), two broilers in each replicate were slaughtered on termination of the experiment.

\section{Analytical procedures}

Nutrient compositions of feed and fecal sample were analyzed as per methods described in Association of Official Analytical Chemists [9].

\section{Statistical analysis}

The data obtained during experiment were analyzed statistically using the methods described by Snedecor and Cochran [10]. Differences among the treatments were tested for significance by Duncan's new multiple range test.

\section{Results}

\section{Performance of broilers}

The observations regarding weight gain (g/bird), feed intake (g/bird), FER, and performance index of broilers in all the three treatment groups $\left(\mathrm{T}_{1}, \mathrm{~T}_{2}\right.$, and $T_{3}$ ) are presented in Table-2. Supplementation of multicarbohydrases enzyme in the diets of broilers influenced their body weight gain significantly. Minimum and significantly $(\mathrm{p}<0.05)$ lower body weight gain (2240.60 \pm 87.97$)$ was observed in broilers assigned negative control $\left(\mathrm{T}_{2}\right)$ diet. However, when the broilers fed energy deficient diet supplemented with multicarbohydrases $\left(T_{3}\right)$, the body weight gain (2663.20 \pm 59.31$)$ was improved significantly $(\mathrm{p}<0.05)$. Feed intake (g/bird) was statistically similar in all the three groups irrespective of dietary treatments.

Supplementation of multicarbohydrases enzyme in the diets of broilers significantly influenced their feed efficiency. Minimum and significantly $(p<0.05)$ lower FER $(0.464 \pm 0.02)$ was observed in broilers assigned negative control $\left(\mathrm{T}_{2}\right)$ diet. When the broilers fed low energy diet was supplemented with multicarbohydrases $\left(\mathrm{T}_{3}\right)$, the FER $(0.574 \pm 0.01)$ was improved significantly $(\mathrm{p}<0.05)$. Minimum and significantly $(p<0.05)$ lower performance index $(1041.16 \pm 10.91)$ was observed in broilers assigned negative control $\left(\mathrm{T}_{2}\right)$ diet, however it was improved significantly $(\mathrm{p}<0.05)$ in $\mathrm{T}_{3}$ group $(1530.23 \pm 52.41)$ supplemented with multicarbohydrases.

\section{Retention of nutrients (\%)}

The observations regarding retention of nutrients (\%) in various groups are presented in Table-3. Minimum and significantly $(\mathrm{p}<0.05)$ lower $\mathrm{CP}$ 
Table-1: Ingredients and nutrient composition of different broiler diets.

\begin{tabular}{|c|c|c|c|c|c|c|c|c|c|}
\hline \multirow[t]{2}{*}{ Attributes } & \multicolumn{3}{|c|}{ Prestarter diet } & \multicolumn{3}{|c|}{ Starter diet } & \multicolumn{3}{|c|}{ Finisher diet } \\
\hline & $\mathbf{T}_{1}$ & $\mathbf{T}_{2}$ & $\mathbf{T}_{3}$ & $\mathbf{T}_{1}$ & $\mathbf{T}_{2}$ & $\mathbf{T}_{3}$ & $\mathbf{T}_{1}$ & $\mathbf{T}_{2}$ & $\mathbf{T}_{3}$ \\
\hline \multicolumn{10}{|l|}{ Ingredient composition (\%) } \\
\hline Maize & 49.58 & 49.58 & 54.78 & 50.13 & 49.58 & 49.58 & 54.78 & 54.78 & 54.78 \\
\hline Soya bean cake & 41.50 & 41.50 & 34.50 & 39.80 & 41.50 & 41.50 & 34.50 & 34.50 & 34.50 \\
\hline Oil & 4.50 & 4.39 & 6.60 & 6.00 & 5.89 & 5.89 & 6.71 & 6.60 & 6.60 \\
\hline LSP & 1.30 & 1.30 & 1.20 & 1.25 & 1.30 & 1.30 & 1.20 & 1.20 & 1.20 \\
\hline $\mathrm{DCP}$ & 1.75 & 1.75 & 1.70 & 1.75 & 1.75 & 1.75 & 1.70 & 1.70 & 1.70 \\
\hline Methionine & 0.30 & 0.30 & 1.00 & 0.30 & 0.30 & 0.30 & 1.00 & 1.00 & 1.00 \\
\hline Lysine & 0.23 & 0.23 & 0.60 & 0.23 & 0.23 & 0.23 & 0.60 & 0.60 & 0.60 \\
\hline Salt & 0.35 & 0.35 & 0.35 & 0.35 & 0.35 & 0.35 & 0.35 & 0.35 & 0.35 \\
\hline Trace mineral premix* & 0.12 & 0.12 & 0.12 & 0.12 & 0.12 & 0.12 & 0.12 & 0.12 & 0.12 \\
\hline Vitamin premix** & 0.03 & 0.03 & 0.03 & 0.03 & 0.03 & 0.03 & 0.03 & 0.03 & 0.03 \\
\hline \multicolumn{10}{|c|}{ Nutrient composition analyzed (\%) } \\
\hline $\mathrm{CP}$ & 23.20 & 23.16 & 23.10 & 22.20 & 22.26 & 22.18 & 20.26 & 20.20 & 20.10 \\
\hline $\mathrm{Ca}$ & 1.09 & 1.02 & 1.08 & 1.07 & 1.09 & 1.06 & 1.02 & 1.07 & 1.04 \\
\hline Total P & 0.77 & 0.72 & 0.75 & 0.75 & 0.77 & 0.75 & 0.77 & 0.75 & 0.76 \\
\hline \multicolumn{10}{|c|}{ Nutrient composition calculated } \\
\hline Energy (kcal ME/kg diet) & 3000 & 2900 & 2900 & 3100 & 3000 & 3000 & 3200 & 3100 & 3100 \\
\hline Lysine \% & 1.33 & 1.33 & 1.33 & 1.24 & 1.24 & 1.24 & 1.18 & 1.18 & 1.18 \\
\hline Methionine \% & 0.52 & 0.52 & 0.52 & 0.54 & 0.54 & 0.54 & 0.47 & 0.47 & 0.47 \\
\hline
\end{tabular}

*Each kg of trace mineral premix contains: Cu - $15 \mathrm{~g}$; Co $-02 \mathrm{~g}$; Fe $-60 \mathrm{~g} ; \mathrm{Zn}-80 \mathrm{~g}$; Mn - $80 \mathrm{~g}$; I $-02 \mathrm{~g} ; \mathrm{Se}-0.3 \mathrm{~g}$.

**Each $\mathrm{kg}$ of vitamin premix contains: Vitamin A - $80 \mathrm{MIU}$; vitamin $\mathrm{D}_{3}-12 \mathrm{MIU}$; vitamin $\mathrm{E}-70 \mathrm{~g}$; vitamin $\mathrm{K}_{3}-8 \mathrm{~g}$; vitamin $\mathrm{B}_{1}-6.4 \mathrm{~g}$; vitamin $\mathrm{B}_{2}-40 \mathrm{~g}$; vitamin $\mathrm{B}_{6}-12.8 \mathrm{~g}$; vitamin $\mathrm{B}_{12}-160 \mathrm{mg}$; Nicotinic acid - $80 \mathrm{~g}$; Folic acid $-4 \mathrm{~g}$; Biotin - $24 \mathrm{mg}$. $\mathrm{CP}=$ Crude protein, $\mathrm{LSP}=$ Limestone powder, $\mathrm{DCP}=$ Dicalcium phosphate

Table-2: Performance of broilers as influenced by multicarbohydrases supplementation (0-6 weeks).

\begin{tabular}{lccc}
\hline Attributes & \multicolumn{3}{c}{ Treatments } \\
\cline { 2 - 4 } & $\mathbf{T}_{\mathbf{1}}$ & $\mathbf{T}_{\mathbf{2}}$ & $\mathbf{T}_{\mathbf{3}}$ \\
\hline Weight gain (g/bird) & $2517.40^{\mathrm{b}} \pm 18.50$ & $2240.60^{\mathrm{c}} \pm 87.97$ & $2663.20^{\mathrm{a}} \pm 59.31$ \\
Feed intake (g/bird) & $4780 \pm 25.30$ & $4825 \pm 19.75$ & $4640 \pm 30.25$ \\
FER & $0.527^{\mathrm{b}} \pm 0.01$ & $0.464^{\mathrm{c}} \pm 0.02$ & $0.574^{\mathrm{a}} \pm 0.01$ \\
Performance index & $1326.00^{\mathrm{b}} \pm 22.62$ & $1041.16^{\mathrm{c}} \pm 10.91$ & $1530.23^{\mathrm{a}} \pm 52.41$ \\
\hline
\end{tabular}

$a, b, c$ Mean \pm standard error bearing similar superscripts in the same row does not differ significantly $(p<0.05)$. FER=Feed efficiency ratio

Table-3: Retention of nutrients (\%) and carcass yields (\% of live weight) in broilers as influenced by multicarbohydrases supplementation (0-6 weeks).

\begin{tabular}{lccr}
\hline Attributes & \multicolumn{3}{c}{ Treatments } \\
\cline { 2 - 4 } & $\mathbf{T}_{\mathbf{1}}$ & $\mathbf{T}_{\mathbf{2}}$ & $\mathbf{T}_{\mathbf{3}}$ \\
\hline Retention of nutrients (\%) & & & \\
DM & $68.39 \pm 2.46$ & $66.50 \pm 0.97$ & $70.04 \pm 0.87$ \\
CP & $61.39^{\mathrm{ab}} \pm 1.15$ & $57.73^{\mathrm{b}} \pm 1.19$ & $64.45^{\mathrm{a}} \pm 1.01$ \\
EE & $61.53^{\mathrm{b}} \pm 1.33$ & $55.02^{\mathrm{c}} \pm 1.19$ & $63.65^{\mathrm{a}} \pm 1.32$ \\
CF & $52.51 \pm 0.76$ & $49.80 \pm 0.55$ & $54.50 \pm 1.25$ \\
NFE & $84.60 \pm 1.50$ & $78.45 \pm 0.80$ & $89.75 \pm 1.25$ \\
Carcass yields (\% of live weight) & & & \\
Dressed weight & $79.59^{\mathrm{b}} \pm 1.4$ & $76.31^{\mathrm{b}} \pm 1.22$ & $84.41^{\mathrm{a}} \pm 1.29$ \\
Eviscerated weight & $69.58^{\mathrm{b}} \pm 3.35$ & $66.44^{\mathrm{b}} \pm 1.65$ & $72.05^{\mathrm{a}} \pm 1.43$ \\
Drawn weight & $72.25^{\mathrm{b}} \pm 1.61$ & $70.59^{\mathrm{b}} \pm 1.39$ & $79.62^{\mathrm{a}} \pm 1.29$
\end{tabular}

$a, b, c$ Mean \pm standard error bearing similar superscripts in the same row does not differ significantly $(p<0.05)$.

$\mathrm{DM}=$ Dry matter, $\mathrm{EE}=$ Ether extract, $\mathrm{CP}=$ Crude protein, $\mathrm{CF}=$ Crude fiber, $\mathrm{NFE}=$ Nitrogen free extract

$(57.73 \pm 1.19)$ and $\mathrm{EE}(55.02 \pm 1.19)$ retention (\%) was observed in broilers of $\mathrm{T}_{2}$ group assigned negative control diet. However, maximum and significantly $(\mathrm{p}<0.05)$ higher CP $(64.45 \pm 1.01)$ and $\mathrm{EE}(63.65 \pm 1.32)$ retention (\%) was observed in broilers of $\mathrm{T}_{3}$ group supplemented with multicarbohydrases. Retention of other nutrients, i.e., DM, CF, and NFE was not affected by the supplementation of multicarbohydrases in broiler diet.

\section{Carcass traits}

The observations regarding carcass yield (\% of live weight) in various groups are presented in Table- 3 . Maximum and significantly $(\mathrm{p}<0.05)$ highest dressed, eviscerated and drawn weights (\% of live weight) were recorded in $\mathrm{T}_{3}$ groups broilers fed multicarbohydrases supplemented energy deficit diet, however it remained statistically similar in $T_{1}$ and $T_{2}$ groups. 


\section{Discussion}

Minimum and significantly lowest weight gain (g/bird) was recorded in group $\mathrm{T}_{2}$ in which ME was reduced by $100 \mathrm{kcal} / \mathrm{kg}$ diet however; weight gain was improved significantly after multicarbohydrases supplementation in $\mathrm{T}_{3}$ group fed energy deficit diet. Addition of multicarbohydrases to maize-based diet increases ileal and total tract digestibilities of CP and starch which could the direct reason for the improvement of growth performance in broilers [11]. Results regarding significantly higher weight gain in multicarbohydrases supplemented group are consistent with Cowieson and Adeola [12] who reported 14\% improvement in weight gain after supplementing enzyme cocktail (xylanase, amylase, protease, and phytase) in broilers fed nutritionally marginal diets. Jose et al. [13] also reported improvement in body weight gain of broilers after supplementation of carbohydrases (amylase+xylanase) in negative control diet. Similar results were also reported by Avila et al. [14] and Zeng et al. [15] where they stated that the supplementation with both NSP-degrading enzymes (xylanase and $\beta$-glucanase) and phytase to the broiler diets increased their body weight.

The results of this study indicated that when the broilers were fed low energy density diet supplemented with carbohydrases enzymes (xylanase $50 \mathrm{~g} /$ ton+mannanase $50 \mathrm{~g} /$ ton+amylase $40 \mathrm{~g} /$ ton), feed intake (g/bird) was not influenced statistically. In support this, Zhang et al. [11] also reported that supplementation of multicarbohydrases enzyme did not affect the feed intake of broilers but increase their body weight gain significantly indicating improved feed efficiency.

In this study, significantly better $(p<0.05)$ feed efficiency and performance index were observed in broilers assigned low energy diet supplemented with multicarbohydrases $\left(\mathrm{T}_{3}\right)$; however, minimum and significantly lower $(\mathrm{p}<0.05)$ feed efficiency and performance index were observed in $\mathrm{T}_{2}$ group fed negative control diet. Similar results were reported by Zanella et al. [16], who observed improved FCR in broiler chickens fed multicarbohydrases enzyme supplemented corn-soy diet. These results regarding better feed efficiency and performance index in multicarbohydrases supplemented group are also supported by Jose et al. [13].

Retention (\%) of CP and EE was significantly $(p<0.05)$ improved in broilers fed diets supplemented with multicarbohydrases (xylanase $50 \mathrm{~g} /$ ton+mannanase $50 \mathrm{~g} /$ ton+amylase $40 \mathrm{~g} /$ ton). These results are in agreements with Olukosi et al. [17] who reported that the supplementation of enzyme cocktail in the negative control diet improved total tract retention of nutrients. Tang et al. [18] reported that supplementation of combination of enzymes (xylanase, amylase, and protease) significantly $(\mathrm{p}<0.05)$ improved apparent ileal digestibility of $\mathrm{CP}$, which is in agreement with our results. Similarly, Zhang et al. [11] also reported that addition of enzyme (xylanase) to maize-based diet has the capacity to increase ileal and total tract digestibilities of $\mathrm{CP}$ and starch which could be the direct reason for the improvement of growth performance in broilers. Retention of other nutrients, viz., DM, CF, and NFE was not influenced by supplementation of multicarbohydrases in this study.

In present study significantly $(\mathrm{p}<0.05)$ higher carcass yield (\% of live weight) in terms of dressed weight, eviscerated weight and drawn weight was found in broilers fed low energy diet supplemented with multicarbohydrases (xylanase $50 \mathrm{~g} /$ ton+mannanase $50 \mathrm{~g} /$ ton+amylase $40 \mathrm{~g} /$ ton). In support to present results, Khan et al. [19] reported significantly improved $(\mathrm{p}<0.05)$ dressing percentage in broilers fed carbohydrases treated sunflower-corn based diets compared to unsupplemented one. Yuan et al. [20] also stated that enzyme supplementation to broilers diet improved their dressing percentage. Similarly, Wang et al. [21] and Hajati et al. [22] reported increased carcass yield in broilers by addition of enzymes in diet attributable to higher fat deposition in carcass. Recently Mishra et al. [23] and Imran et al. [24] also reported maximum value of dressing percentage in broilers fed carbohydrases supplemented diet.

\section{Conclusion}

From the results of the present experiment, it was concluded that multicarbohydrases (xylanase at $50 \mathrm{~g} /$ ton +mannanase at $50 \mathrm{~g} /$ ton+amylase at $40 \mathrm{~g} /$ ton) supplementation improved overall performance of broilers fed low energy diets.

\section{Authors' Contributions}

SN and RPSB have designed the plan of work. KG conducted the experiment, carried out the laboratory work and analyzed the results. AKP and CDM drafted and DT revised the manuscript. All the authors read and approved the final manuscript.

\section{Acknowledgments}

The authors are thankful to the Dean, College of Veterinary Science and Animal Husbandry, Jabalpur, for providing financial support (NDVSU Endt no. 850/compt/Budgetr/2014) and necessary laboratory facilities to carry out this research.

\section{Competing Interests}

The authors declare that they have no competing interests.

\section{References}

1. Cowieson, A.J. (2010) Strategic selection of exogenous enzymes for corn-soya based poultry diets. J. Poult. Sci., 47: 1-7.

2. Ravindran, V. (2013) Feed enzymes: The science, practice, and metabolic realities. J. Appl. Poult. Res., 22(3): 628-636.

3. Leslie, M.A., Moran, E.T.Jr. and Bedford, M.R. (2007) The effect of phytase and glucanase on the ileal digestible energy of corn and soybean meal fed to broilers. J. Poult. 
Sci., 86: 2350-2357.

4. Gracia, M.I., Aranibar, M.J., Lazaro, R., Medel, P. and Mateos, G.G. (2003) Alpha-amylase supplementation of broiler diets based on corn. J. Poult. Sci., 82: 436-442.

5. Jeichitra, V. and Srinivasan, G. (2013) Influence of multi-carbohydrases on growth performance of Nandanam colour broilers. Int. J. Food Agric. Vet. Sci., 3: 63-65.

6. Purushothaman, M.R., Kathirvelan, C., Chandrasekaran, D., Vasanthkumar, P. and Senthilkumar, S. (2013) Efficacy of supplemental mannose on corn soya diet. Indian J. Poult. Sci., 48: 169-172.

7. BIS. (2007) Nutrient Requirements of Poultry. Bureau of Indian Standards, New Delhi, India.

8. Bird, J.M. (1955) Performance of growing chicken. J. Poult. Sci., 34: 1163-1164

9. AOAC. (2012) Official Methods of Analysis. 19 $9^{\text {th }}$ ed. Association of Official Analytical Chemists, Gaithersburg, Maryland, USA.

10. Snedecor, G.W. and Cochran, W.G. (2004) Statistical Methods. $9^{\text {th }}$ ed. The Iowa State University Press, Ames, Iowa, USA.

11. Zhang, L., Xu, J., Lei, L., Jiang, Y., Gao, F. and Zhou, G.H. (2014) Effect of multi-carbohydrases supplementation on growth performance, nutrient digestibility and non-starch polysaccharide degradation in different sections of the gastrointestinal tract of broilers fed wheat based diets. Asian Australas. J. Anim. Sci., 27: 855-886.

12. Cowieson, A.J. and Adeola, O. (2005) Carbohydrases, proteases and phytase have an additive beneficial effect in nutritionally marginal diets for broiler chicks. Poult. Sci., 84: 1860-1867.

13. Jose, O.B., Alice, E.M., Eliane, S.N., Francisco, P., Alexandra, P. and Rafael, L.H. (2009) Enzymatic programs of broilers. Braz. Arch. Biol. Technol., 52: 233-240.

14. Avila, E., Arce, J., Soto, C., Rosas, F., Ceccantini, M. and McIntyre, D.R. (2012) Evaluation of an enzyme complex containing non-starch polysaccharide enzymes and phytase on the performance of broilers fed a sorghum and soybean meal diet. J. Appl. Poult. Res., 21: 279-286.

15. Zeng, Q., Huang, X., Luo, Y., Ding, X., Bai, S., Wang, J., Xuan, Y., Su, Z., Liu, Y. and Zhang, K. (2015) Effects of multi-enzyme complex on growth performance, nutrient utilization, and bone mineralization on meat duck. J. Anim.
Sci. Biotechnol., 6: 2-8.

16. Zanella, I.N., Sakomura, K., Silverside, F.G., Fiqueirdo, A. and Pack, M. (1999) Effect of enzyme supplementation of broiler diets based on corn and soybeans. J. Poult. Sci., 78: 561-568.

17. Olukosi, O.A., Cowieson, A.J. and Adeola, O. (2008) Energy utilization and growth performance of broilers receiving diets supplemented with enzymes containing carbohydrase or phytase activity individually or in combination. Br. J. Nutr., 99: 682-690.

18. Tang, D., Hao, S., Liu, G., Nian, F. and Ru, Y. (2014) Effect of maize source and complex enzymes on performance and nutrient utilization of broilers. Asian Australas. J. Anim. Sci., 27: 1755-1762.

19. Khan, S.H., Sardar, R. and Siddique, B. (2006) Influence of enzymes on performance of broiler fed sunflower corn based diets. Pak. Vet. J., 26: 109-114.

20. Yuan, J., Junhu, Y., Fengxia, Y., Xiaodan, Y., Xinjie, W., Jincheng, H., Yaojie, W., Xinke, C., Yurui, L., Zhenfeng, Z., Ningbo, Z. and Xinyu, F. (2008) Effects of supplementing different levels of a commercial enzyme complex on performance, nutrient availability, enzyme activity and gut morphology of broilers. Asian Australas. J. Anim. Sci., 21: 692-700.

21. Wang, Z.R., Qiao, S.Y., Lu, W.Q. and Li, D.F. (2005) Effects of enzyme supplementation on performance, nutrient digestibility, gastrointestinal morphology, and volatile fatty acid profiles in the hindgut of broilers fed wheat-based diets. Poult. Sci., 84: 875-881.

22. Hajati, H., Rezaei, M. and Sayyahzadeh, H. (2009) The effects of enzyme supplementation on performance, carcass characteristics and some blood parameters of broilers fed on corn-soybean meal-wheat diets. Int. J. Poult. Sci., 8: 1199-1205.

23. Mishra, A., Sarkar, S.K., Ray, S. and Haldar, S. (2013) Effects of partial replacement of soybean meal with roasted guar korma and supplementation of mannanase on performance and carcass traits of commercial broiler chickens. Vet. World., 6: 693-697.

24. Imran, M., Pasha, T.N., Akram, M., Mehmood, K. and Sabir, A.J. (2014) Effect of ß-mannanase on broilers performance at different dietary energy levels. Glob. Vet., 12: 622-626.

\section{$* * * * * * * *$}

